\title{
From Colonialism to the New Millennium and Beyond
}

\section{Adebayo Olukoshi}

\begin{abstract}
1 Introduction
It is not such a long time ago since ' 40 years' was the average life expectancy of a human being anywhere in the world, and under different historical circumstances we might have gathered for a funeral mass or remembrance ceremony rather than to celebrate a fortieth anniversary. But the relentless pace of human progress on all fronts during the nineteenth and twentieth centuries mean that longer average life expectancies have emerged as the norm and it appears to be almost within our grasp to master disease and poverty.
\end{abstract}

And yet, it is one of the supreme ironies of our times that, because of in-built unevenness and imbalances in the human quest for progress, we still find ourselves caught in a world of sharp contrasts that add up to diminish our collective achievements. Thus, while in one part of the world one of the key challenges arising is the problem of ageing populations; in another part of the same world, the part that constitutes the global South and within which Africa is nested, one of the biggest problems centres on the falling average life expectancies for a significant number, and a population that is overwhelmingly youthful in profile.

Depending, therefore, on the part of the world in which we find ourselves, reaching the age of 40 could convey very different meanings: the beginning of the end or the end of the beginning - or even a grey zone between the two.

\section{Trajectories of development}

Taking a longer historical view, we might conclude that the high hopes raised by the seemingly relentless pace of progress made the late nineteenth and early twentieth centuries the heyday of development. Prometheus seemed truly to be unbound and, to reiterate a metaphor coined by Leo Huberman (founder of Monthly Review), man's worldly goods accumulated in leaps and bounds, and the promise of a better life was in the air.

It was in the name of this progress, ideologised into a civilising mission and the white man's burden, that Europe was to pursue foreign conquests and colonies, radically redrawing the map of the modern world according to its image and interests. I shall return later to the implications of this flipside of progress. Still, it bears pointing out at this point that even within the colonial project, especially in the postwar period, there was what Anne Phillips referred to in her 1989 book, The Enigma of Colonialism, as the ideology of development, an ideology that was born of structural and conjunctural factors that need not detain us here. It was in this immediate postwar period that President Truman launched his 'development era'.

It was also in this context that development research and studies as a distinct field began to emerge, combining concerns about how wealth can be created and sustained at ever higher levels with an active interest in understanding why poverty persists and how it might be overcome. Economics was the privileged discipline for this task and there were important intellectual investments made in the evolution of a sub-field or sub-discipline of development economics. But economics was far from being alone - anthropology, sociology, geography, political science, history and international relations all joined in the fray, drawing from their different disciplinary perspectives to feed the debates that became the stuff of development research.

Thanks to the contributions of development researchers, the conceptual distinction between growth and development was gradually established and a new consensus agreed that, although development cannot occur without growth, unless interventionist measures are introduced, growth can 
never on its own serve as a sufficient condition for development. Arguments raged about the conditions that make growth possible, the prerequisites for translating growth into development and the strategies for sustaining development. Uniformly, policy was to settle for an answer that called for infusions of foreign capital in the form of loans and aid. The possibilities of the transfer of knowledge and technology were explored. This was the standard response for bridging the growing global divide, and soon an aid industry was to boom.

The notion of development itself, often overlapping with a sense of progress, was to undergo considerable refining, going beyond wealth creation and wealth distribution to encompass leisure, happiness, gender equality, environmental sustainability, intergenerational socioeconomic rights, etc. The gradual expansion of the notion of the development to incorporate these issues - contested in some circles - both reflected and interfaced with a feeling of unease that although humankind was, on aggregate, registering great progress, that greatness was also being diminished by the numerous dysfunctionalities that were in evidence. Of the dysfunctionalities that were identified as making development less robust than it should be, none focused our attention more than the North-South or centre-periphery asymmetries that appeared to be worsening in the 1960s and 1970s and which were used by the underdevelopment/dependency school to challenge the various strands of modernisation theory that had, hitherto, been dominant, and which had their specific disciplinary expressions.

The question that was posed could be summarised very simply as follows: Why was one half of the world registering development and the other half not? Was the development of the one half that was progressing occurring at the expense of the other half that appeared to be stagnating? Why were some countries so hopelessly dependant on others?

Views were varied on these questions and the answers proffered displayed differing degrees of nuance. But although the underdevelopment/dependency school had many weaknesses, perhaps its single most important contribution was to challenge the idea most widely expressed in the Rostowian five stages of economic growth that developing countries were condemned to follow the exact paths that had been trodden decades earlier by the developed countries in order to progress.
Thus the end of the age of innocence in the development debate was first signalled by this success of the underdevelopment/dependency school. It projected the concerns of the developing countries onto an international developmental architecture that was underpinned by power relations that didn't give them much of a fighting chance. Mainstream development research was seen as predominantly irrelevant at best and obstructive at worse, promoting arguments which seemed weighted in favour of the preservation of a status quo that was neither tenable nor sustainable.

Politicians and policymakers in developing countries seized the moment to push for a new international order that would be fairer to all. Their campaigns were to be joined by a variety of interests, ranging from environmentalists, gender/feminist activists and trade unionists seeking to expand labour rights, among others. These campaigns established a notion of development that was tied to the radical transformation of the status quo. Such concepts as 'Another Development' (particularly popular in the Nordic countries) came to the fore in discussions of a new world order. Other notions emerged, like sustainable development, a forerunner to human development, and Schumacher's 'small is beautiful'/ 'small is possible'.

In this context, the business of development was increasingly seen as going way beyond the concerns of high-minded aid workers or innocent Peace Corps volunteers to speak more boldly and directly to rooting out the structural foundations of underdevelopment, or mal-development as some put it. The time for mere palliatives to cushion the problems of the poor seemed to be over. Social movements for local and global change flourished in this framework, expounding projects of social transformation. Solidarity in action was their watchword, and in its name they called on transnational corporations to be more accountable.

But looking back at the powerful forces with which the new international order movement was in confrontation, one may be tempted to think of that era as a somewhat romantic one that did not sufficiently reckon with what it would take to dislodge entrenched interests. The reliance on the United Nations system to push the frontiers of change came up against the constraints of inter-state diplomacy. Social movements sown from below 
sought change through an umbrella framework constructed from above.

The economic and political contexts of the quest for a new order was to be changed radically by the oil shocks of the 1970s, the final death of the gold standard, the decline of Keynesianism in domestic policymaking and the rise of conservative regimes in the key centres of global accumulation - the USA, the UK, Germany and Canada. The collapse of the Soviet Union and the system it had spawned in Eastern Europe and the end of the Cold War completed the cycle of change.

The shift that occurred took place alongside the rise of a neoliberal ideology that had been in the making since the early 1970s, and which took a hegemonic position on economic questions. Where Keynesians saw employment generation as a key concern for policymaking, the neoliberals defined inflation as public enemy No 1. Where Keynesians recognised market imperfections or incompleteness and thus saw an active role for public policymaking via the state, the neoliberals proclaimed the evilness, or wickedness and inefficiency of the state, which they contrasted to perfect and efficient markets. Yesterday's public enterprises, including those that emerged from nationalisation, were earmarked for privatisation. Whatever was left in the public domain was to be subjected to a market logic.

Development concerns that appeared to be settled at the core of the post-1945 Keynesian world were mercilessly assaulted and relegated to the background. As to the champions of a new world order, the neoliberals found no time of the day for them: the new name of the game was a free and open market. No wonder some commentators were to say that the neoliberal onslaught was nothing short of a counter-revolution which turned settled ideas on their head and proclaimed the birth of a bold new era. The TINA ideology (Margaret Thatcher's famous 'there is no alternative') was proclaimed and conditionality was deployed to deliver compliance among developing countries. International financial institutions born out of Keynesian ideals were hijacked by the neoliberals and transformed into the omnipotent enforcers of the new market orthodoxy.

Emboldened by the support of key developed country governments, and spurred by initial successes in taming rampaging inflation in the leading $O E C D$ economies, the neoliberals were to proclaim two victories: the death of inflation and the death of development. As we know, this turned out to be a rather premature victory cry, but while it lasted it had many development researchers scrambling for cover and adopting the new orthodoxy for various reasons, including the fear of irrelevance.

But in its theoretical underpinnings and in its practice, neoliberalism was replete with contradictions. These contradictions have been detailed by several scholars well known to us, - Jomo Kwame Sundaran, Ha Joon Chang, Joseph Stiglitz and Finn Tarp, to name a few. The contradictions of the neoliberal agenda added up to ensure that it was never able to deliver on most of its promises. In serving as the ideological underbelly for a market-driven process of globalisation, it opened new problems and compounded existing ones. Inequalities at various levels re-asserted themselves with a vengeance and local social dislocations accompanied them, resonating on a global scale.

In the face of the failures of the neoliberal agenda, the self-assured confidence of its frontline ideologues was eventually tempered and the Bretton Woods institutions that, a decade earlier, had been reconfigured to serve as the prime enforcers of the narrow market orthodoxy became more humble as the growing calls for a new post-Washington consensus framework became too loud to ignore. By the end of the 1990s, neoliberalism had been backed into a corner - but it was far from defeated. For while there was a consensus that neoliberal policies were problematic, several factors prevented the emergence of credible alternatives that could transcend them, Thus, new policy interventions, such as the Poverty Reduction Strategy Papers, continued to be underpinned by neoliberal macroeconomic assumptions that rendered them counter-productive. Part of the explanation for this must lie in the stars of development research that seem to have led us into a dead-end.

This is roughly where we find ourselves today. We entered the new millennium with more questions than ever, questions that are complicated by the discontents and asymmetries of a neoliberal orthodoxy that created domestic and global maladjustments.

The harvest from maladjustment is plentiful: migration driven by want and hopelessness, the xenophobic reactions it tends to generate and the fortress solutions that are proposed; the collapse of central governmental 
authority, especially in Africa; uncontrolled urbanisation; de-agrarianisation which has gone hand-in-hand with de-industrialisation in some places; the collapse in others of the middle classes and, with their decline, the collapse of the middle ground in politics; the increasing burden placed on large numbers of women and the widening of gender inequalities; the spread of human trafficking. Extremes of various kinds, fundamentalisms of various shades compete with criminality and the deployment of extreme violence. Extreme wealth and poverty stand face-to-face in a confrontation that constantly threatens a breakdown of order.

Of course, not all countries and regions of the world have felt the impact of maladjustment to the same degree and not all have displayed the same degree of incapacity to work with and overcome its effects. Indeed, some have been able to adapt themselves in order to fill niches arising from maladjustment and the global re-ordering which is being engineered. At one end of the problem of maladjustment, the receiving end, stands Africa; at the other end, the gaining end, stands China as a symbol of the shifts in the redistribution of power that is going on and from which India is also benefiting. Still, because of the closer integration of the world economy, it is safe to assume that all countries and fiscal actors will feel the effects of maladjustment.

Tomorrow's historians may well look back on this era and conclude that, as with the crisis of the early twentieth century, especially the depression of the interwar years, and America's rise following the Second World War, which shifted the locus of global power away from Europe and served as the context for the consolidation of the American century, we may be witnessing the beginnings of another shift, this time eastwards with China at its epicentre and India and other emergent players in its outer circles.

Shifts of this nature come with their own anxieties, even discontents: multilayered uncertainties about jobs that might be lost in some places, industrial sectors that might be wiped out, social welfare systems that will be eroded - the list is not exhaustive. History teaches us that no socioeconomic change of the magnitude that is currently taking place passes without friction and a global realignment of forces and interests will underpin the new balance of power that will emerge. This time too, it is accompanied by new democratic pressures and citizen concerns for a greater say.
That is why questions are being asked around the world about what the Chinese age will mean for other players in the development game: Will China be a benign or hegemonic power? What opportunities will the Chinese age create for some and which doors will close for others? The questions are many and the answers are still largely speculative. Between the lingering effects of neoliberal adjustment and the challenges which the rise of China poses - political, economic, social, environmental and cultural, development research clearly has its work cut out. The question is: are we equipped for the intellectual challenges that arise?

\section{The challenges for development research}

I would suggest that our capacity to rise to the challenges posed by the changing global and local contexts of development will depend on our willingness to reinvent ourselves constantly in order to become more adequate for the tasks at hand. Further, we cannot reinvent successfully without addressing some of the key weaknesses that marred our previous efforts at contributing, through knowledge production, to the goal of securing human welfare, freedom and happiness in an environment of peace and democracy.

The first of the weaknesses that must be overcome is connected to the weight which the origins of development research, as we came to know it, bears on the trade. As with Area Studies in the USA, development research emerged out of the needs of powerful policy interests in the period of late colonialism. These origins meant that development research was from its very beginnings a discussion about the other. This may not necessarily have been a bad thing in and of itself except that the discourse became, effectively, how to make the developing countries become like the developed countries.

In this framework, the development problems of the developed countries were never sufficiently engaged and the development problems of the developing countries were read through the prism of the history of the developed countries. That history was itself so highly sanitised so as to empty it of contestation and contradiction. Idealised versions of the history of development in the West were produced against which the experiences of the developing countries were measured. Factors that acted as triggers were presented as undisputed historical fact. And yet, in internal discussions in the Western academy, these 
factors and the importance of each of them continues to be the object of debate, as indeed they should be.

Effectively, two parallel discussions were taking place: one preoccupied with development in the West and the other, Western-driven that drew in a stylised, unproblematised fashion from the historical experiences of the West, to interpret and pronounce on development in the South. In the end, although Rostow may have been an extreme example of this approach, he was by no means an exception.

Failing to relate adequately to the internal dynamics of the developing countries and the historical contexts that shape them, development research tended to be ahistorical and was carried out by analogy. Unilinear evolutionism was rampant. In policy terms, it reduced the practice of development in much of the South to an exercise in mimicry. Aid dependency and massive extremes and debt burden were the inevitable outcome.

This approach to development research did not go unchallenged and a significant number of critics were attempted to contest the validity of the pathologies which allegedly set developing countries apart from the developed countries. In the same vein, the predilection to characterise similar processes differently was questioned. We need to evolve a unified development discourse underpinned by solid comparative methods and not simple analogies. We cannot continue to read the histories of the South through the histories of the North.

A second related weakness has to do with the failure to engage with the intellectual production of the countries whose experiences are being studied. In place of such an engagement, local knowledge from the West is hegemonised and presented as universally valid. This may partly explain why we have been too quick to look for formulaic solutions to problems that do not lend themselves easily to such approaches.

Third, and too frequently we have resorted to employing binary frames to dichotomise complex realities, with the consequence that we lose the nuance and expunge the messy bits that are as important for a proper understanding of the processes we seek to study. Evolving a unified discourse is not to encourage the idea of a one-sizefits-all model of development thinking. One of the challenges which we currently face is the need to rediscover our capacities to study development in its pluralism and diversity, also tapping into the history and cultural contexts of different peoples. No two routes to development are the same and the margins for choice in the policy process must be defended.

As I noted earlier, development research and development cooperation have a long history of association which may not necessarily be unhealthy. However, in funding development research, the policy community has also appropriated a greater role for itself in setting the pace and choosing what is studied - and even, at times, how it is studied. In its worst form, this has made development research appear to be the voicepiece of development cooperation. But it has also meant as rapid a turnover of agenda as fashions in development cooperation change. Is this not the reason why some critics have worried aloud that development research is now increasingly about buzz words and fads at the altar of which patient, longitudinal research is sacrificed?

Furthermore, the concepts we use to try to capture the realities we confront have become increasingly inadequate. This much was registered by the report of the Gulbenkian Commission on the restructuring of social sciences which Wellerstein chaired. It is true that development research at its best is multidisciplinary. But in its multidisciplinarity, it is still disproportionally driven by specific disciplinary anchors that make an integrated discourse difficult. Yet, the business of development, inscribed as it is in history, culture, psychology, geography and environment, cannot be grasped fully if caged within specific disciplinary boundaries.

If development research is to be meaningful and relevant, we need to invest more in multidisciplinary approaches that are capable of generating new, commonly shared concepts that better enable us to capture the many types and layers and boundaries that define modern livelihoods.

In light of this, it will also be important to challenge the hegemony of orthodox macroeconomics and the pressure other disciplines feel to mimic its methods and adopt its assumptions. The social science roots of development research and its qualitative tools must not be sacrificed but should be rediscovered.

Above all, the desire for technical solutions to development problems, while useful when properly 
placed in context, sometimes take on a life of its own with the consequence that we forget that development is about people and that what they think and how they feel matters. The Millennium Development Goals (MDGs) may be lofty in their ambitions, but set in a technocratic mould, they play down the realities of unequal power relations that continue to rule the world economy and which make the question of global economic and political governance an urgent one to which development researchers must pay close attention.

Over the last 40 years, IDS has been successful in reinventing itself by adapting to changing circumstances and I am confident that it will continue to do so. The current challenges of development are plentiful, so there will be a continuing need for research. The new dimensions to the challenges brought about by the current context of globalisation means that there will be room for continuing innovation and adaptation. But for this spirit of innovation to be complete, we must listen more and more to endogenous voices and engage them in ways that make our conversations less incestuous and our methodologies less self-fulfilling

This calls for learning on all sides to do things differently; breaking barriers in order to build the kind of comparative knowledge that draws from different local contexts and knowledges and which might be better adapted to the needs of both the state and non-state policy communities that require such knowledge. Only then might development research become a powerful tool for social transformation. 